\title{
Reclamation of Sodic-Saline Soils. Barley Crop Response
}

\author{
Giovanni Lacolla, Giovanna Cucci* \\ Dipartimento di Scienze delle Produzioni Vegetali, Università di Bari \\ Via Amendola 165/A, 70125 Bari, Italy
}

Received: 21 July 2008. Accepted: 5 November 2008.

\begin{abstract}
The research was aimed at assessing the salinity and sodicity effects of two soil types submitted to correction on barley crop.

The two soils, contained in cylindrical pots $(0.40 \mathrm{~m}$ in size and $0.60 \mathrm{~m} \mathrm{~h})$ supplied with a bottom valve for the collection of drainage water and located under shed to prevent the leaching action of rainfall, were clay-textured and saline and sodic-saline at barley seeding, as they had been cultivated for 4 consecutive years with different herbaceous species irrigated with 9 types of brackish water.

In 2002-2003 the 2 salinized and sodium-affected soils (ECe and ESP ranging respectively from $5.84-20.27 \mathrm{dSm}^{-1}$ to $2.83-11.19 \%$ ), submitted to correction, were cultivated with barley cv Micuccio, and irrigated with fresh water (ECW $=0.5 \mathrm{dS} \mathrm{m} \mathrm{m}^{-1}$ and SAR $=0.45$ ) whenever $30 \%$ of the maximum soil available moisture was lost by evapotranspiration. Barley was shown to be a salt-tolerant species and did not experience any salt stress when grown in soils with an initial ECe up to $11 \mathrm{dS} \mathrm{m} \mathrm{m}^{-1}$. When it was grown in more saline soils (initial ECe of about $20 \mathrm{dS} \mathrm{m}^{-1}$ ), despite the correction, it showed a reduction in shoot biomass and kernel yield by $26 \%$ and $36 \%$ respectively, as compared to less saline soils.
\end{abstract}

Key-words: soil reclamation, salinity and sodicity, barley.

\section{Introduction}

The irrigation practice has extensively developed in the second half of last century (Qadir and Oster, 2004); from the mid-60s to the '80s it has favoured a $50 \%$ increase in the overall food production (El-Ashry and Duda, 1999).

Although irrigated lands account for $18 \%$ only of world-cultivated areas (FAO, 2005), 40\% of food production is supplied by irrigated farming (UNCSD, 1997), and this percent is estimated to increase to $50 \%$ within 2040 (FAO, 1988).

The world population growth and the subsequent increase in food demand have brought about a sharp increase in irrigation water requirements to increase crop yields. The increase in fresh water demand for agriculture is con- fronted both with the scarcity in water resources and with the great competition for use of the civil and industrial sectors. In many areas, notably in Southern Italy, good quality water resources are not constant through the years but they vary following the seasonal rainfall patterns; actually, prolonged drought periods often occur for several years, thus hampering a proper planning of water resources management.

To meet the growing and conflicting needs of society, it is now common to use for irrigation even poor quality non-conventional resources, such as brackish, drainage and waste water (Bouwer, 2000; Pereira et al., 2002).

Many Authors agree that the use of brackish water is a serious problem for about one third of world-irrigated areas (Cavazza, 1968; Ayers and Westcot, 1985; Pasternack and De

\footnotetext{
* Corresponding Author: Tel.: +39 80 5443005; Fax: +39 80 5442976. E-mail address: giovanna.cucci@agr.uniba.it The research was performed within the project COFIN-PRIN 2003 of the Ministero dell'Istuzione e della Ricerca. Rome, Italy.
} 
Malach, 1987; Graifenberg et al., 1993; Ghassemi et al., 1995).

This problem is particularly urgent in arid and semi-arid areas where about $50 \%$ of irrigated areas suffer from soil salinity problems. In the Mediterranean region, featured by high evapotranspirative demand, scarcity of leaching rainfall and recurrent seawater intrusion in coastal aquifers, saline water $\left(\mathrm{EC}>1 \mathrm{dS} \mathrm{m}^{-1}\right)$ is already used in fresh water-deficient areas, such as North Africa and Middle East (Katerji et al., 2002; Fagnano et al., 2004). Many North Mediterranean coastal areas are today affected by the gradual salinization of their water resources; unluckily the continued water abstraction that results in aquifer depletion and sea-water intrusion, as well as the unexpected effects of climate change make the use of increasingly poor water resources more likely in the future, even in the coastal areas of Greece, Italy, France and Spain (Fagnano et al., 2004). According to Postel (1996) the salt-affected areas are increasing at an alarming rate, i.e. by about 2 million hectares per year. The problems related to secondary salinization do not only concern the crop response to the use of brackish water for irrigation (short term effect) but mostly the longterm changes that could reduce soil productivity (Cucci et al., 2003) so much as to make farming impossible. Alterations and dangerous modifications are mainly due to the sodium ion concentration that may cause clay deflocculation with the subsequent reduction of soil water conductivity, if is not counterbalanced by calcium and magnesium divalent ions (Sequi, 1989).

In general, in the regions with a more humid climate the leaching action of rainfall can favour the natural washing of salts, whereas in arid and semi-arid areas with poor rainfall, salt leaching might be artificially induced by the application of adequate watering volumes.

Indeed, in arid climate areas, the leaching of the salts applied with the brackish water used for irrigation is often favoured by applying an excess of water to the required quantity ( $\mathrm{LR}=$ leaching requirement): its value depends on the amount of salts contained in the soil; the water salinity; the residual salinity in the concerned soil layer depending on the tolerance of the cultivated species. Soil salinity management and control is one of the main challenges of the agricultural sector in the XXI century, especially where irrigation is practiced (Amezketa, 2006).

Barley (Hordeum vulgare) is an important crop that can grow and produce in marginal lands often characterized by drought and low temperatures. Its yield is used for animal and human nutrition and for malting.

Barley, sugar beet and cotton are among the most salt-tolerant species (Maas and Hoffman, 1977; Ayers and Westcot, 1985; Francois and Maas, 1994; Maas and Grattan, 1999), but they are relatively sensitive at germination and at the seedling stage (Bernstein and Hayward, 1958; Ungar, 1974). Based on the indicators of crop sensitivity to salinity, as proposed by Maas and Hoffmann (1977), barley crop has a critical threshold of the saturation extract electrical conductivity of $8 \mathrm{dS} \mathrm{m}^{-1}$ and a $5 \%$ slope.

Hussain et al. (1997) conducted a research on five barley cultivars irrigated with water of increasing salinity and a $15 \%$ LR (leaching requirement); they observed a reduction in the germinating ability as compared to the control of $24-35,28-47,30-53 \%$ when the crop was irrigated with water with an EC of 9.26, 13.4 and $16.28 \mathrm{dS} \mathrm{m}^{-1}$ respectively, whereas they obtained satisfactory forage barley yields when using an irrigation water with an EC till $9.26 \mathrm{dS} \mathrm{m}^{-1}$.

Hamdy et al. (2005) investigated the possibility to apply supplemental irrigation to wheat and barley at crop sensitive stages (flowering and seed formation) using brackish water with an EC level from 3 to $9 \mathrm{dS} \mathrm{m}^{-1}$ : they obtained $21 \%$ mean barley yield reductions as compared to the control irrigated with fresh water; instead without any supplemental irrigation they observed $100 \%$ barley yield drops.

Al-Tahir et al. (1997) reported on barley crop irrigated with three types of water of different salt content and fertilised with different nitrogen rates; when using drainage water with an average EC of $14 \mathrm{dS} \mathrm{m}^{-1}$ and low nitrogen rates, he observed a drop in the number of stems with a subsequent reduction in grain and straw yield.

Other research works investigated some physiological aspects (Isla et al. 1997; Munns R., 2002), the influence of irrigation water on germinating ability, and some yield parameters (Hussain et al., 1997; Iyengar et al., 1984; Koszanski et al., 1985; Abdul et al., 1988; Heakal et al., 1990; Aragüés et al., 1994). Instead the literature on the effects of soil salinity and sodic- 
ity, the influence of correction on crop productivity is still poor.

In saline-alkaline soils the leaching of soluble salts using fresh water is not sufficient and may even deteriorate the characteristics while removing salinity, thus making soils alkaline. This is the reason to recommend the combination of the leaching action of water with soil correction aimed to favour the removal of sodium excess.

The objective of the research was to assess the combined effects of soil correction, salinity and sodicity (leaching and application of calcium sulphate) on barley crop grown in two soil types irrigated for four years with sodic-saline water.

\section{Materials and methods}

The trial was run at the Campus of the Agricultural Faculty of Bari University (Italy) in two soil types contained in cylindrical pots, $0.40 \mathrm{~m}$ in size and $0.60 \mathrm{~m} \mathrm{~h}$ supplied with a bottom valve for the collection of drainage water and located under shelter to prevent the leaching action of rainfall.

The two soil types, both rich in clay material, with a mean electrical conductivity of the saturation extract (ECe) of $0.67 \mathrm{dS} \mathrm{m}^{-1}$ and a mean exchangeable sodium percentage (ESP) of $0.75 \%$, have been characterized as follows (Cavazza et al., 2002; Patruno et al., 2002): 1) Bologna soil $\left(\mathrm{T}_{1}\right)$ - with clay mineral rich in vermiculite and illite, is poor in iron and aluminium sesquioxides, taken from the AP horizon, of a Udertic Ustochrept (fine, mixed, mesic), Mon- tefalcone series, of Emilia Romagna soil map; 2) Locorotondo soil $\left(T_{2}\right)$ - with clay mineral rich in illite and kaoline, is rich in iron and aluminium sesquioxides, taken from the AP Horizon Pachic Haploxeroll (fine, mixed, thermic), Cutino series, of Apulia soil map; this soil type is common in the area South-East of Bari.

At barley seeding the two soil types were saline and sodic-saline as they had been cultivated in the previous four years with different herbaceous species (borlotto bean, pepper, sunflower, wheat) irrigated with 9 types of brackish water obtained by dissolving the appropriate amounts of $\mathrm{NaCl}$ and $\mathrm{CaCl}_{2}$ in de-ionised water so as to obtain the factorial combination of 3 salt concentration levels (0.001-0.01-0.1 mol $\mathrm{l}^{-1}$ in 1999 and $0.01-0.032$ and $0.064 \mathrm{~mol} \mathrm{l}^{-1}$ in the following years) with 3 SAR levels (5-15-45) (Tab. 1) and submitted to two different leaching fractions (10 and $20 \%$ of the watering volume).

The research was conducted on 72 total pots applying the split plot experimental design with 2 replicates, with soil types in large plots (18 pots), leaching levels in sub-large-plots (9 pots) and water, types in plots (single pots).

After four-year irrigation with sodic-saline water the ECe was closely related to the salt concentration of irrigation water, shifting from 5.47 to 10.04 and to $18.23 \mathrm{dS} \mathrm{m}^{-1}$ for the soil $\mathrm{T}_{1}$ and from 6.22 to 12.32 and $22.30 \mathrm{dS} \mathrm{m}^{-1}$ for $\mathrm{T}_{2}$ respectively when irrigated with water of salt concentration levels of $0.01,0.032$ and 0.064 (Tab. 2). The ESP of the two soils has also increased considerably with irrigation water salinity, with values of $3.15,6.28$ and $11.68 \%$ for soil $\mathrm{T}_{1}$ and of $2.50,6.11$ and $10.61 \%$ for soil $\mathrm{T}_{2}$ when

Table 1. Quality characteristics of water used for irrigation in the first year (1999) and in subsequent years (2000-2001 and 2002).

\begin{tabular}{lrcrrr}
\hline & \multicolumn{2}{c}{ Year 1999} & \multicolumn{2}{c}{ Years 2000-2001-2002 } \\
\hline Salt concent. ( $\left.\mathrm{mol} \mathrm{l}^{-1}\right)$ & SAR & ECw $\left(\mathrm{dS} \mathrm{m}{ }^{-1}\right)$ & Salt concent. $\left(\mathrm{mol} \mathrm{l}^{-1}\right)$ & SAR & ECw $\left(\mathrm{dS} \mathrm{m}{ }^{-1}\right)$ \\
\hline 0.001 & 5 & 0.13 & 0.01 & 5 & 1.47 \\
0.001 & 15 & 0.12 & 0.01 & 15 & 1.24 \\
0.001 & 45 & 0.12 & 0.01 & 45 & 1.19 \\
0.01 & 5 & 1.47 & 0.032 & 5 & 4.65 \\
0.01 & 15 & 1.24 & 0.032 & 15 & 3.86 \\
0.01 & 45 & 1.19 & 0.032 & 5 & 3.59 \\
0.1 & 5 & 13.55 & 0.064 & 15 & 11.30 \\
0.1 & 15 & 11.18 & 0.064 & 45 & 9.60 \\
0.1 & 45 & & & 8.95 \\
\hline
\end{tabular}


Table 2. Electrical conductivity of the saturation extract (ECe) and exchangeable sodium percentage (ESP) of the 2 soils irrigated for four years with sodic-saline water (means depth 0-0.2, 0.2-0.4, 0.4-0.6 m).

\begin{tabular}{lccccc}
\hline Treatments & \multicolumn{3}{c}{ Bologna soil $\left(\mathrm{T}_{1}\right)$} & \multicolumn{2}{c}{ Locorotondo soil $\left(\mathrm{T}_{2}\right)$} \\
\hline Salt concen. $\left(\mathrm{mol} \mathrm{l}^{-1}\right)$ & SAR & ECe $\left.(\mathrm{dS} \mathrm{m})^{-1}\right)$ & ESP $(\%)$ & ECe $\left.(\mathrm{dS} \mathrm{m})^{-1}\right)$ & ESP $(\%)$ \\
\hline 0.01 & 5 & 6.01 & 3.06 & 7.55 & 2.26 \\
& 15 & 5.48 & 3.12 & 6.31 & 2.58 \\
& 45 & 4.91 & 3.29 & 4.80 & 2.66 \\
\hline Mean & & 5.47 & 3.16 & 6.22 & 2.50 \\
\hline 0.032 & 5 & 12.00 & 4.65 & 15.32 & 4.63 \\
& 15 & 9.32 & 7.21 & 11.84 & 4.93 \\
& 45 & 8.11 & 6.98 & 9.80 & 8.77 \\
\hline Mean & & 9.81 & 6.28 & 12.32 & 6.11 \\
\hline 0.064 & 5 & 21.05 & 8.61 & 24.15 & 8.37 \\
& 15 & 18.00 & 12.58 & 21.80 & 11.44 \\
& 45 & 15.64 & 13.86 & 20.96 & 12.01 \\
\hline Mean & & 18.23 & 11.68 & 22.30 & 10.61 \\
\hline
\end{tabular}

irrigated with water with salt concentration levels equal to $0.01,0.032$ and $0.064 \mathrm{~mol} \mathrm{l}^{-1}$, respectively (Tab. 2). In the text and the tables the salt concentration $\left(0.01,0.032\right.$ and $\left.0.064 \mathrm{~mol} \mathrm{l}^{-1}\right)$ levels of irrigation water are those applied in the three-year period from 2000 to 2002.

Prior to barley sowing the soil contained in pots was adequately treated and supplied with calcium sulphate (for the soils with an ESP > 6\%) at the maximum rate of $2 \mathrm{Mg} \mathrm{ha}^{-1}$ equivalent.

The multiple-row barley cv. Micuccio was sown on 19.12 .02 placing the seeds on 2 rows per pot; 60 seeds per pot were sown so as to obtain a density of about 300 plantlets per $\mathrm{m}^{2}$. Fertilization was achieved applying $60 \mathrm{~kg} \mathrm{ha}^{-1}$ of $\mathrm{N}(30 \%$ applied at sowing and the remaining $70 \%$ just prior to tillering), $100 \mathrm{~kg} \mathrm{ha}^{-1}$ of $\mathrm{P}$ and $50 \mathrm{~kg} \mathrm{ha}^{-1}$ of $\mathrm{K}$; phosphorus and potassium were incorporated before barley sowing.

Throughout the cropping cycle the crop was irrigated using water of low salt content $(0.5 \mathrm{dS}$ $\mathrm{m}^{-1}$ and low SAR level $(0.45)$ whenever $30 \%$ of the maximum available moisture was lost by evapotranspiration. The applied water corresponded to the volume required to restore the field capacity in the whole soil mass contained in each pot (measured directly in pots by weighing through dynamometric scale) plus a calculated leaching fraction. For more saline soils the applied leaching fractions were $20 \%$ and proportionately lower for less saline soils, till the electrical conductivity and the SAR of drainage water equalled respectively $3 \mathrm{dS} \mathrm{m}^{-1}$ and 9 .
The crop management was applied following the local cultural practices. Barley was harvested on June 19th 2003; the treatments irrigated in the previous four-year period with water of high salt concentration level $\left(0.064 \mathrm{~mol} \mathrm{l}^{-1}\right)$ showed a vegetative delay; harvest was continued till 1st of July 2003. At harvest the morphological, yield and quality parameters of barley were statistically processed by the GLM, SAS/STAT procedure; the difference between mean values was estimated applying the SNK test.

\section{Results and discussion}

The seasonal water volumes, ranging between 61 and 55 litres (equivalent to 488 and $440 \mathrm{~mm}$ ), were applied to each pot in 22-23 applications. No differences were observed in relation to the number of water applications, because the plants cultivated in the soils with higher ECe (24.0 and $24.4 \mathrm{dS} \mathrm{m}^{-1}$ ) experienced a slowing down in the early growth stages due to salt stress leading to a subsequent extension of the cycle by about 20 days, as compared to the plants cultivated in less saline soils, and additional water applications. For the seasonal irrigation volumes, no sharp difference was observed, because the lower water consumptive use of the plants cultivated in more saline soils was counterbalanced by the higher leaching application in relation to the higher EC (electrical conductivity) of drainage water, as compared to less saline soils. 
The application of leaching water has favoured the removal of soluble salts with a subsequent progressive reduction of the EC of drainage water from the initial values of 6.6, 13.4 and $24.0 \mathrm{dSm}^{-1}$, observed for the soil $\mathrm{T}_{1}$ and of 8.1, 15.1 and $24.4 \mathrm{dS} \mathrm{m}^{-1}$, found for $\mathrm{T}_{2}$, to the late season values of $3.2,5.9$ and $10.5 \mathrm{dS} \mathrm{m}^{-1}$, for the first soil and 3.2, 6.6 and $11.6 \mathrm{dS} \mathrm{m} \mathrm{m}^{-1}$ for the second soil, respectively, shifting from poor to moderate and higher soil salinity levels (Fig. 1).

The SAR of drainage water has also gradually decreased after the application of subsequent leaching fractions from $10.1,12.8$ and 18.8 to 5.3 , 8.6 and 10.7, for the soil $\mathrm{T}_{1}$ and from 10.7, 13.3 and 19.5 to $5.6,9.1$ and 11.1 , for $\mathrm{T}_{2}$, respectively when irrigated with water of salt concentration levels of $0.01,0.032$ and $0.064 \mathrm{~mol} \mathrm{l}^{-1}$ (Fig. 2).

The removal of soluble salts had a beneficial effect on the physico-chemical soil properties. Many research works have proved the beneficial effects of calcium sulphate application on the physico-chemical properties of sodic-saline soils: it increases permeability and leaching (Frenkel et al., 1989; Baumhardt et al., 1992;
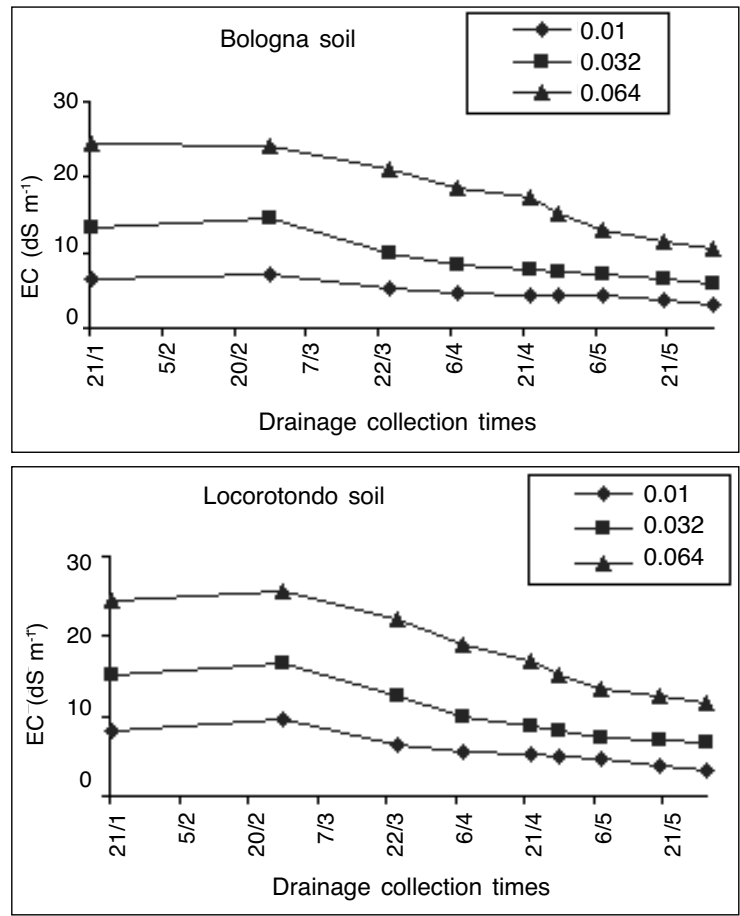

Figure 1. Evolution of drainage water electrical conductivity in the two soils during barley growing season, as related to the salt concentration of the irrigation water used in the previous four years (1999-2002).
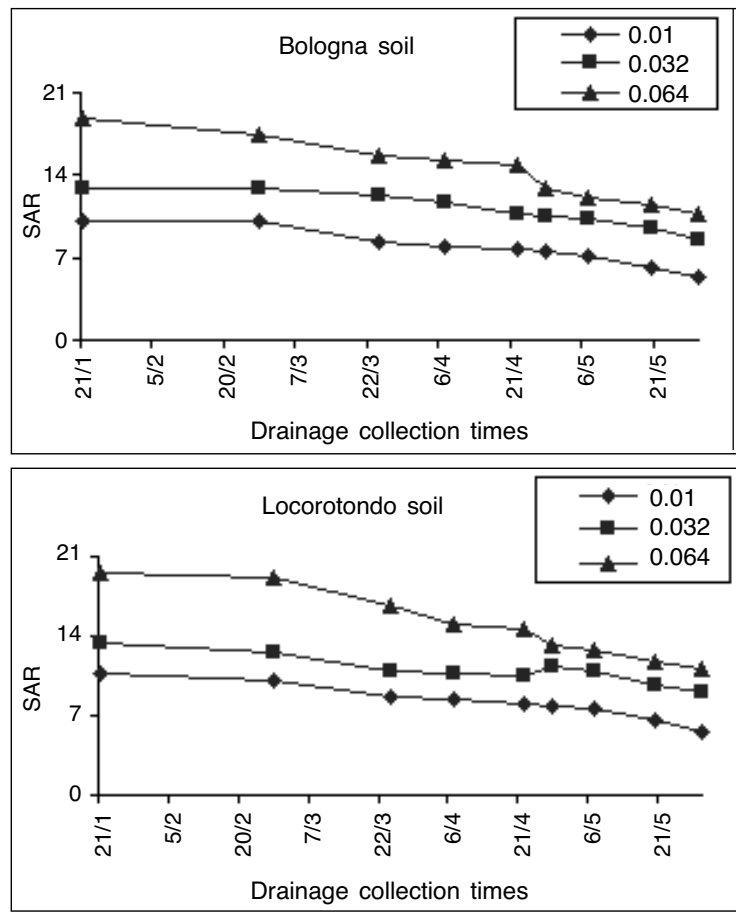

Figure 2. Evolution of the SAR of drainage water in the two soils throughout barley growing season, as related to the salt concentration of the irrigation water used in the previous four years (1999-2002).

Ilyas et al., 1997), favours soil flocculation and macroporosity (Chartres et al., 1985; Greene et al., 1988), reduces bulk density (Southard et al., 1988) and surface crusting (Gal et al., 1984).

\subsection{Effects of the soil type on barley crop}

Barley crop has not showed any significant differences at germination, emergence and at the subsequent growth stages in relation to the two soil types (both clay) on which it had been grown. The soil $\mathrm{T}_{2}$ (containing illite and kaolin clay minerals, and rich in iron and aluminium) was positively affected by some yield parameters, such as the number of ears per pot $(+13.2)$, the dry biomass $(+9.2)$ and grain yield $(+11.2)$ as compared to the crop grown in the soil type $\mathrm{T}_{1}$ (containing vermiculite and illite clay minerals, and poor in iron and aluminium sesquioxides) (Tab. 3, Fig. 3). El-Dardiry (2007) has also observed differences in the response of barley grown on soils irrigated with sodic-saline water and amended with organic matter and calcium sulphate as related to soil particle-size. 
Table 3. Morphological, yield and quality parameters of barley cultivated in 2 soils irrigated for four years with sodic-saline water (1999-2000), as related to the soil type, the salt concentration and the SAR of irrigation water.

\begin{tabular}{lrrrrrrrr}
\hline Yield parameters ${ }^{(1)}$ & \multicolumn{2}{c}{ Soil types } & \multicolumn{3}{c}{$\begin{array}{c}\text { Salt concentration of } \\
\text { irrigation water }\left(\mathrm{mol} \mathrm{l}^{-1}\right)\end{array}$} & \multicolumn{2}{c}{ SAR of irrigation water } \\
\cline { 2 - 9 } & \multicolumn{1}{c}{$\mathrm{T}_{1}$} & \multicolumn{1}{c}{$\mathrm{T}_{2}$} & 0.01 & 0.032 & 0.064 & 5 & 15 & 45 \\
\hline Tillers $\left(\mathrm{n} \mathrm{pot}^{-1}\right)$ & $147 \mathrm{~A}$ & $154 \mathrm{~A}$ & $151 \mathrm{~A}$ & $145 \mathrm{~A}$ & $156 \mathrm{~A}$ & $150 \mathrm{~A}$ & $151 \mathrm{~A}$ & $150 \mathrm{~A}$ \\
Tillers plant $^{-1}$ & $2.9 \mathrm{~A}$ & $3.1 \mathrm{~A}$ & $3.0 \mathrm{~A}$ & $2.9 \mathrm{~A}$ & $3.1 \mathrm{~A}$ & $3 \mathrm{~A}$ & $3 \mathrm{~A}$ & $3 \mathrm{~A}$ \\
Plant height $(\mathrm{m})$ & $0.79 \mathrm{~B}$ & $0.86 \mathrm{~A}$ & $0.86 \mathrm{~A}$ & $0.85 \mathrm{~A}$ & $0.77 \mathrm{~B}$ & $0.83 \mathrm{~A}$ & $0.84 \mathrm{~A}$ & $0.82 \mathrm{~A}$ \\
Spikes $\left(\mathrm{n} \mathrm{pot}{ }^{-1}\right)$ & $121 \mathrm{~B}$ & $137 \mathrm{~A}$ & $137 \mathrm{~A}$ & $134 \mathrm{~A}$ & $116 \mathrm{~B}$ & $127 \mathrm{~A}$ & $132 \mathrm{~A}$ & $128 \mathrm{~A}$ \\
1000 seed weight $(\mathrm{g})$ & $43.9 \mathrm{~A}$ & $43.2 \mathrm{~A}$ & $44.3 \mathrm{~A}$ & $45.1 \mathrm{~A}$ & $41.3 \mathrm{~B}$ & $43.5 \mathrm{~A}$ & $43.8 \mathrm{~A}$ & $43.4 \mathrm{~A}$ \\
Hectolitre weight $\left(\mathrm{kg} \mathrm{hl}^{-1}\right)$ & $71.2 \mathrm{~A}$ & $70.9 \mathrm{~A}$ & $72.9 \mathrm{~A}$ & $73.2 \mathrm{~A}$ & $67.1 \mathrm{~B}$ & $71.4 \mathrm{~A}$ & $71.0 \mathrm{~A}$ & $70.0 \mathrm{~A}$ \\
\hline
\end{tabular}

( ${ }^{1}$ For each effect considered, the values followed by the same letter are not significantly different, according to the SNK test at $\mathrm{P} \leq 0.01$.

\subsection{Effects of soil salinity and sodium on barley crop}

The crop cultivated in soils irrigated in the previous four years with water of lower salt concentration $\left(0.01 \mathrm{~mol} \mathrm{l}^{-1}\right)$ was not

negatively affected by salinity. At barley sowing time, the ECe values of moderately saline soils $\left(0.032 \mathrm{~mol} \mathrm{l}^{-1}\right)$ were slightly above the critical threshold (ECe $8 \mathrm{dS} \mathrm{m}^{-1}$ ) indicated by Maas and Hoffman (1977) and Ayers and Westcot (1985); after the application of the leaching fraction, however, they decreased below the critical threshold. Therefore, neither the crop cultivated on these soils was negatively affected by salinity. No significant differences were observed in the morphological and yield parameters under consideration (Tab. 3, Fig. 3).

On the other hand,) at barley sowing time, the soils previously irrigated with water of higher salt concentration $\left(0.064 \mathrm{~mol} \mathrm{l}^{-1}\right)$, had an average ECe greater than $20 \mathrm{dS} \mathrm{m}^{-1}$, which caused a $50 \%$ yield reduction (Ayers and Westcot, 1985). Actually, in these more saline soils the germinating ability was slightly reduced (about 10\%) and emergence was delayed by about 20 days as compared to the crop grown in soils previously irrigated with water of lower concentration $\left(0.01 \mathrm{~mol} \mathrm{l}^{-1}\right)$. Other works too (Storey and Jones, 1978) report that barley is more sensitive to salinity at germination and at emergence, and becomes more tolerant as it gets older. The two researchers have mostly attributed salt stress for barley at emergence to the ionic rather than osmotic effects. Shamberg et al. (1989) report that the salt stress has a negative effect on seed germination both for the poor water uptake and for the toxic effect due to the accumulation of $\mathrm{Na}$ and $\mathrm{Cl}$ ions that result in an imbalanced absorption of nutrients.

As a consequence of salt stress, the plants, grown in the soils with a higher initial ECe (24.0 and $24.4 \mathrm{dS} \mathrm{m}^{-1}$ ), showed a stunted growth

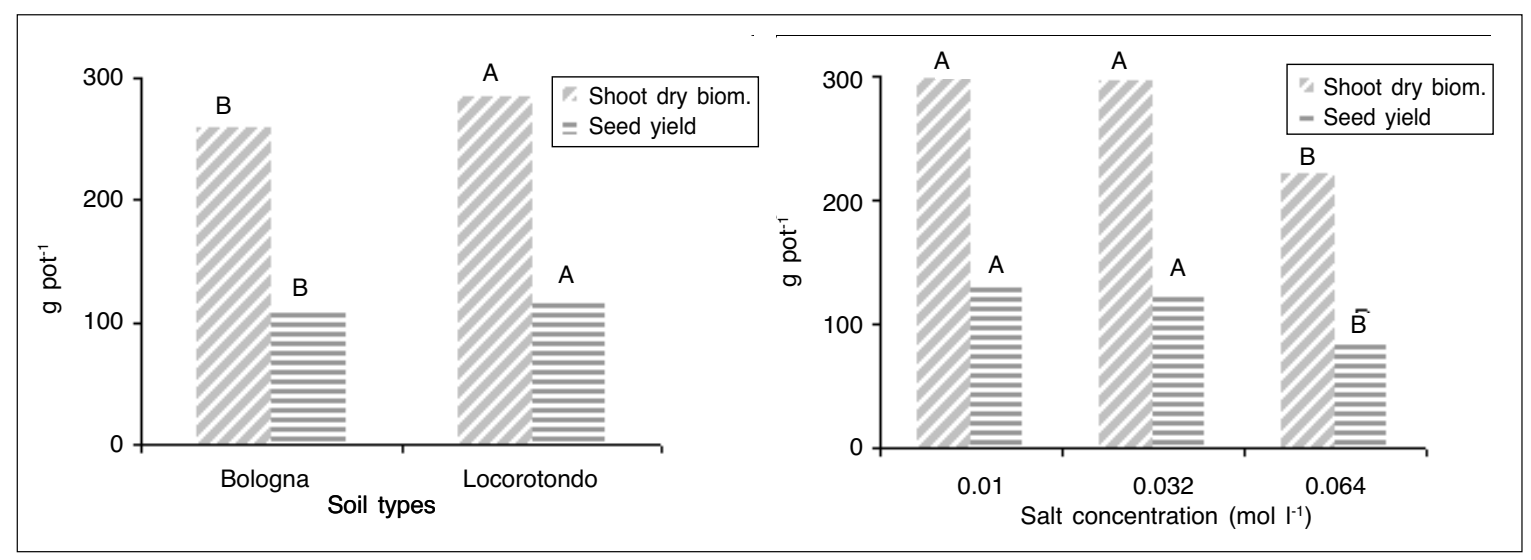

Figure 3. Variation of the shoot biomass and barley grain yields as influenced by the soil type and the salt concentration of the irrigation water used in the previous four years (1999-2002).

For each effect considered, the values followed by the same letter are not significantly different, according to the SNK test at $\mathrm{P} \leq 0.01$. 
throughout all the growing season, with a delay of all growth stages, notably germination, emergence and tillering with a staggered emission of poorly developed infertile stems. This caused a $14 \%$ average reduction in the number of ears per pot and their scalar ripening as compared to the two lower saline treatments. These short size plants displayed a sharp apical necrosis in the elder leaves, and some malformations, besides a green-bluish colour. Hence in these soils, despite the drop in salinity induced by the application of $20 \%$ leaching fraction, and the ESP reduction due to the application of soil amendments (calcium sulphate), the shoot biomass decreased by $26 \%$, spikes by $15 \%$ and kernel yield per pot decreased by $36 \%$ as compared to the crop cultivated in less saline soils (Tab. 3, Fig. 3). In terms of quality, the kernels were shrunken and showed a $10 \%$ reduction in the hectolitre and 1000 seed weight (Tab. 3). (1997) In a trial on a barley crop irrigated with three types of saline water with mean EC values of 3.1, 7.9 and $14 \mathrm{dS} \mathrm{m}{ }^{-1}$, Al-Tahir et al. (1997) found, in the crop irrigated with water of higher salinity, a $21.1 \%$ reduction in kernel yield and a $9.6 \%$ decrease in straw yield as compared to the crop irrigated with water of lower salinity. The reduction in kernel yield has been mostly attributed to the reduction in the number of ears and to the kernel weight.

\section{Conclusions}

The application of calcium sulphate to alkaline soils and the use of a $20 \%$ leaching fraction in more saline soils and proportionately lower fractions in less saline soils till electrical conductivity and SAR values of drainage water reached about $3 \mathrm{dS} \mathrm{m}^{-1}$ and 9, caused a large reduction in salinity and alkalinity in both soils allowing barley crop to grow and produce kernels.

Actually barley was shown to be a salt-tolerant species and did not experience any salt stress when cultivated in soils with an initial ECe of 6 and $11 \mathrm{dS} \mathrm{m}^{-1}$, irrigated in the previous four years with water of salt concentration levels of 0.01 and $0.032 \mathrm{~mol} \mathrm{l}^{-1}$ respectively. On the other hand, when barley was cultivated in soils of higher salinity (ECe of about $20 \mathrm{dS} \mathrm{m}^{-1}$ ) previously irrigated with water with a salt concentration of $0.064 \mathrm{~mol} \mathrm{l}^{-1}$, it showed the first typical symptoms caused by salt stress, a stunted development, delay in all growth stages, and a $36 \%$ grain yield reduction, as compared to the same crop cultivated in less saline soils.

The results of this research seem to point out, however, the possibility to use sodic-saline water for irrigation in the Mediterranean region, when prolonged drought cycles do occur for several years with a subsequent reduction of fresh water availability. When fresh water is deficient, it is recommended to save good quality water to irrigate salt-sensitive crops, and use poor quality water for more resistant crops. Soils may be subsequently recovered when rainfall cycles are more favourable and make it possible to apply the higher good quality water resources as a supplement to the leaching volume to wash out the salt build-up without causing a severe soil structure degradation.

\section{References}

Abdul K.S., Alkam F.M., Jamal MA. 1988. Effects of different salinity levels on vegetative growth, yield and its components in barley. Zanco, 1:21-32.

Al-Tahir Osman A., Al-Nabulsi Y.A., Helalia A.M. 1997. Effects of water quality and frequency of irrigation on growth and yield of barley (Hordeum vulgare L.) Agricultural Water Management, 34:17-24.

Amezketa E. 2006. An integrated methodology for assessing soil salinization, a pre-condition for land desertification. Journal of Arid Environments, 67:594-606.

Aragüés R., Royo A., Grattan S.R. 1994. Foliar uptake of sodium and chloride in barley sprinkler irrigates with saline water: effect of pre-irrigation with fresh water. Eur. J. Agronomy, 3:9-16.

Ayers R.S., Westcot D.W. 1985. Water quality for agriculture. Irrigation and Drainage Paper 29. Rev. 1. FAO, Rome. 174 p.

Baumhardt R. L., Wendt C.W., Moore J. 1992. Infiltration in response to water quality, tillage and gypsum. Soil Sci. Soc. Am., 1, 56:261-266.

Bernstein L., Hayward H.E. 1958. Physiology of salt tolerance. Ann. Rev. Plant Physiol., 9:25-46.

Bouwer H. 2000. Integrated water management: emerging issues and challenges. Agric. Water Manag., 45:217-228.

Cavazza L. 1968. Problems of irrigation with brackish water in Italy. In: H. Boiko: Saline irrigation for agriculture and forestry, 53-79. W. Junk, N.V. Pub. L'Aia.

Cavazza L., Patruno A., Cirillo E. 2002. Soil trait and structure stability in artificial sodicated soil. Italian J. of Agronomy, 6, 1:15-25.

Chartres C.J., Greene R.S., Ford G.W, Rengasamy P. 1985. The effect of gypsum on macroporosity and crusting of two red dup soils. Aust. J. Soil Res., 23:467-479.

Cucci G., Rubino P., Caliandro A. 2003. Effects of irri- 
gation water with different salt concentrations and SAR values on soil salinization and sodification. Italian Journal of Agronomy, 7, 1:41-48.

El-Ashy M.T., Duda A.M. 1999. Future perspectives on agricultural drainage. In: Skaggs R.W., van Schilfgaarde J. (eds.): Agricultural drainage, 1285-1298. ASA-CSSA-SSSA, Madison, WI.

El-Dardiry E. 2007. Effect of Soil and Water Salinity on Barley Grains Germination under Some Amendments. World J. Agr. Sci., 3, 3:329-338.

Fagnano M., Quaglietta Chiarandà F. 2004. Relazioni tra qualità dell'ambiente e produzione agricola. Riv. Agron., 38, 33-84.

FAO 2005. FAO, Statistical Databases (FAOSTAT), http://faostat.fao.org/.

FAO 1988. World Agriculture Toward 2000: An FAO Study. N. Alexandratos (ed.). Bellhaven Press, London. 338 pp.

Francois L.E., Maas E.V. 1994 Crop response and management on salt affected soils. In: Pessarakli N. (ed.): Handbook of Plant and Crop Stress, 149-180. M. Dekker, New York.

Frenkel H., Gerstle Z., Alperovitch N. 1989. Exchangeinduced dissolution of gypsum and the reclamation of sodic soils. J. Soil Sci., 40:599-611.

Gal M., Arcan L., Shainberg I., Keren R. 1984. Effect of exchangeable sodium and phosogypsum on crust structure-scanning electron microscope observations. Soil Sci. Sec. Am. J., 48:872-878.

Ghassemi F., Jakeman A.J., Nix H.A. 1995. Salinisation of land and water resources: Human causes, extent, management and case studies. UNSW Press, Sydney, Australia, and CAB International, Wallingford, UK, 1-50.

Grainfenberg A., Lipucci Di Paola M., Giustiniani L. 1993. Yield and growth of globe artichoke under saline-sodic conditions. HortScience, 8:791-793.

Greene R.S.B., Rengasamy P., Ford G.W., Chartres. C.J., Miller J.J. 1988. The effect of sodium and calcium on physical properties and micromorphology of two redbrown earth soils. J. Soil Sci., 39:39-648.

Hamdy A., Sardo V., Farrag Ghanem K.A. 2005. Saline water in supplemental of wheat and barley under rainfed agriculture. Agricultural Water Management, 78:122-127.

Heakal M.S., Modaihsh A.S., Mashhady A.S., Metwally A.I. 1990. Combined effects of leaching fraction salinity and potassium content of waters on growth and water use efficiency of wheat and barley. Plant and Soil, 125, 2:177-184.

Hussain G., Al-Joloud A.A., Al-Shammary S.A., Karimulia S., Al-Aswad S.O. 1997. Effect of saline irrigation on germination and growth parameters of barley (Hordeum vulgare L.) in a pot experiment. Agricultural Water Management, 34:125-135.

Ilyas M., Qureshi R.H, Qadir M.A. 1997. Chemical changes in a saline-sodic soil after gypsum application and cropping. Soil Technology, 10:247-260.

Isla R., Royo A., Aragüés R. 1997. Field screening of barley cultivars to soil salinity using a sprinkler and a drip irrigation system. Plant and Soil, 197:105-117.

Iyengar E.R.R., Chikara I., Sutaria P.M. 1984. Relative salinity tolerance of barley varieties under semi-arid climate. Trans. Indian Soc. Desert Technol. Univ. Centre Desert Studies 9, I:27-33.

Katerji N., van Hoorn J.W., Hamdy A., Mastrorilli M. 2002. Use of non-conventional water resources as a freshwater saving practices. In: Mediterranean crop responses to water and soil salinity: ecophysiological and agronomic analyses. CHIEAM, Bari, Options méditerranées, B, 36, 280.

Koszanski Z., Karczmarvzyk S. 1985. Use of saline water for irrigation of spring barley and oats. Rolnictwo, 36:95-105.

Maas E.V., Hoffman G.J. 1977. Crop salt tolerance - current assessment. J. Irrigation and Drainage Division, ASCE, 103:115-134.

Maas E.V., Grattan S.R. 1999. Crop yields as affected by salinity. In: Skaggs R.W., van Schilfgaarde J. (eds.): Agricultural Drainage, Agron. Monograph, 38:55-108.

Munns R. 2002. Comparative physiology of salt and water stress. Plant, Cell and Environment., 25:239-250.

Pasternak D., De Malach Y. 1987. Saline water irrigation in the Negev desert. Publications section, the Institutes for Applied research, Ben-Gurion University of the Negev, Beer-Sheva, Israel.

Patruno A., Cavazza L., Cirillo E. 2002. Exsperiments on soil sodication. Italian J. of Agronomy, 6, 1:3-13.

Pereira L.S., Oweis T., Zairi A. 2002. Irrigation management under water scarcity. Agri. Water Manag., 57:175-206.

Postel S. 1996. Forging a sustainable water strategy. In: State of the world report 1996, W.W. Norton \& Company, New York, 40-59.

Qadir M., Oster J.D. 2004. Crop and irrigation management strategies for saline-sodic soils and waters aimed at environmentally sustainable agriculture. Science of the Total Environment, 323:1-19.

Sequi P. 1989. Chimica del suolo. Patron Editore. Bologna, 608.

Shamberg I., Sumner M.E., Miller W.P., Farina M.P.W., Pavan M.A., Fey M.V. 1989. Use of gypsum on soils: A Review. Adv. Soil Sci., 9:1-11.

Southard R.J., Shainberg I., Singer M.J. 1988. Influence of electrolyte concentration on the rnicromorphology of artificial depositional crust. Soil Sci. Soc. Am. J., 145:278-288.

Storey R., Jones R.G. 1978. Salt stress and comparative physiology in the gramineae. I. Ion relations of two salt-and water-stressed barley cultivars, California Mariout and Arimar. Aust. J. Plant Physiol, 5:801-816.

Ungar I.A. 1974. The effect of salinity and temperature on seed germination and growth of Hordeum jubatum. Can. J. Bot., 52:1357-1362.

United Nations Commission on Sustainable Development (UNCSD) 1997. Comprehensive assessment of the freshwater resources of the world. Report E/CN.17/1997/9, http: //www.un.org/esa/sustdev/sdissues/water/water_documents.htm. 